ods. Large concentrations of terrestrial gastropods Helix sp. shells were found in the Early and Late Mesolithic layers. These gastropods were the objects of collecting and probably composed a significant part of the primitive communities' diet. Dvoinaya Cave and Chygai Rockshelter belong to series of synchronous Mediterranean, Levant and Zagros sites with large concentrations of grape snails in the late Upper Palaeolithic and Mesolithic layers. The data of the use-wear analysis of stone tools, micro-chemical and IR-spectroscopic analysis of the residues on the stone tools surfaces allow to conclude that the ancient inhabitants of the Gubs Gorge collected and processed various plant resources, including wood, grass fibers, resin of coniferous and fruit plants with the purpose of manufacturing and fastening of handles, frames and shafts of arrows. The river mollusks Theodoxus danubialis shells were used for making beads. More than 30 shells with punched or drilled holes were found in the lowest layer of the Dvoinaya Cave.

Keywords: Stone Age; Upper Paleolithic; Mesolithic; North-Western Caucasus; food resources; shell heap; terrestrial gastropods Helix sp.; fresh-water molluscs Theodoxus danubialis; non-food resources; use-wear analysis; organic residues; microchemical analysis; IR spectroscopy.

УДК $902.034 / 902.3$

DOI 10.24411/2309-4370-2018-14202

Статья поступила в редакцию 02.08.2018

\title{
THE SPATIO-TEMPORAL DYNAMICS OF RESOURCES IN 'WILD' PREHISTORIC LANDSCAPES
} (C) 2018

\author{
Grøn Ole, PhD, researcher of Department of Geosciences and Natural Resource Management \\ University of Copenhagen (Copenhagen, Kingdom of Denmark)
}

Abstract. Based on archaeological and ethnoarchaeological data, this paper discusses the spatio-temporal dynamics of the resources in 'wild' prehistoric landscapes, i.e. landscapes not subjected to techniques related to modern mono-cultural agriculture but potentially managed in other ways. The prevailing assumption in the archaeological environments engaged in modelling of Stone Age settlement positions is, that the resources in such landscapes are rather stable and evenly distributed. Such a concept was, however, abandoned in landscape ecology in the mid-1990s because it did not match the observed environmental reality, and replaced with much more mathematically complex models accepting that the different species (plants as well as animals) tend to appear in highly dynamic 'patches.' Updating both the archaeological debate and research initiatives related to modelling of Stone Age habitation areas is therefore long overdue. A central point in this respect is whether the dynamic spatio-temporal behaviour of the resources in these landscapes is so complex that its reconstruction in specific micro-areas, and thereby a precise modelling of potential Stone Age settlement areas, is impossible. The fact, that human cultural groups opposite animal and plant societies often can be observed to behave different in similar environmental situations due to that they have developed different strategies and traditions, does not leave much hope.

Keywords: topographical landscape modelling; hunter-gatherer settlement patterns; hunter-gatherer economy; resource dynamics; foragers; landscape ecology; patch dynamics; mosaic landscapes; landscape wildfires; effects of storms and flooding.

\section{Introduction}

Topographical/bathymetric predictive modelling plays an increasing role in mapping of potential Stone Age settlement areas, both on land and in landscapes that now lie submerged under water [e.g. 1-5]. This is being undertaken in ways that prompt concern, because they frequently focus exclusively on the topography/bathymetry of the prehistoric landscape surface but ignore the prehistoric vegetation and related resources and their often significant spatio-temporal dynamics. In landscape ecology, it is now well-established that the vegetation tends to form dynamic mosaics which influence smallscale animal and human activities, thereby leading to significant variation in cultural spatial behaviour over time [6-8; 9, p. 246-255; 10, p. 175-228; 11] (fig. 1). This aspect is the main focus of the present paper. A further problem, which will not be addressed here, is that this modelling approach is often based on simplistic and general assumptions about how hunter-gatherers place their settlements in the landscape. It ignores both the archaeological and the ethnoarchaeological evidence, which reveals significant deviations from what is commonly assumed and demonstrates that various huntergatherer cultures can behave differently in similar landscapes: Even individual subgroups of one specific cul- tural group may display significant behavioural differences $[8 ; 12 ; 13]$.

Incorporation of up-dated landscape ecology-based theory into archaeological predictive modelling of the settlement distribution in the landscape obviously renders the discipline more complicated, both theoretically and practically. On the other hand, it introduces a much more realistic relationship to the real world. One can only guess why archaeology has been permitted to select the simple and easy-to-handle modelling principles, while ignoring the more difficult ones, in its attempts to develop rapid and cheap 'desktop' approaches to the mapping of Stone Age settlements. The aim of this paper is to demonstrate how poorly the hitherto applied approach to modelling copes with the variation evident in huntergatherer settlement behaviour, based solely on topography/bathymetry, thereby underpinning the importance of developing new methodologies for either better predictive modelling or, alternatively, direct physical detection of Stone Age settlements.

\section{The landscape concept in hunter-gatherer}

archaeology and landscape ecology

In archaeology, the characteristics of the landscapes inhabited and used by prehistoric hunter-gatherers are generally conceived as congruent with a landscape con- 
Grøn O.

The spatio-temporal dynamics of resources in 'wild' prehistoric landscapes

07.00.00 - исторические науки и археология

cept that was abandoned by landscape ecology in the mid-1990s [e.g. 14]: A marked change has occurred recently within the science of ecology. Previously, ecological processes commonly were assumed to proceed within homogeneous environments, and usually within populations of randomly distributed individuals. Recently it has been widely recognized that environments are not homogeneous, and organisms are usually clumped into patchy populations, and that this heterogeneity has significant effects on ecological processes.

While archaeological landscape modelling imagines landscapes as being rather stable, recent landscape ecological research perceives them as highly dynamic: Different parts of the landscape mosaics progress asynchronously through the various phases of individual 'ecological successions', from burnt patches to climax vegetation, if they manage to progress that far before being burnt down once again. While the horizontal differentiation of species in the landscape into mosaics can result from variations in geochemistry, moisture, shade/sun exposure, vegetation history, storm-damage, etc., a main driver for the dynamics is regularly occurring wildfires [9, p. 194-199; 15] (fig. 1). There are different types of wildfires - ground fires, surface fires, sub-canopy fires and crown fires. These can occur in various combinations and at various intervals, as well as with different types of spread pattern, depending on vegetation type, wind, moisture, slope etc., which have different effects on the landscape $[10$, p. $175-228 ; 16 ; 17$, p. $29 ; 18]$.

Wildfires alone, independent of other factors, are capable of generating landscape complexity and dynamics that make it practically impossible to reconstruct in sufficient detail the prehistoric vegetation and consequent faunal and human spatial behavioural patterns. The task of identifying and dating, in relation to archaeological features, the many significant vegetation changes caused by wildfires, occurring in some areas as often as every 30-40 years [19] (figs. 1, 2), would in itself be an extremely difficult if not impossible task. Even though some modelling approaches include vegetational data at a general basic level, they lack a significant part of the picture required for mapping Stone Age sites [e.g. 2; 20].

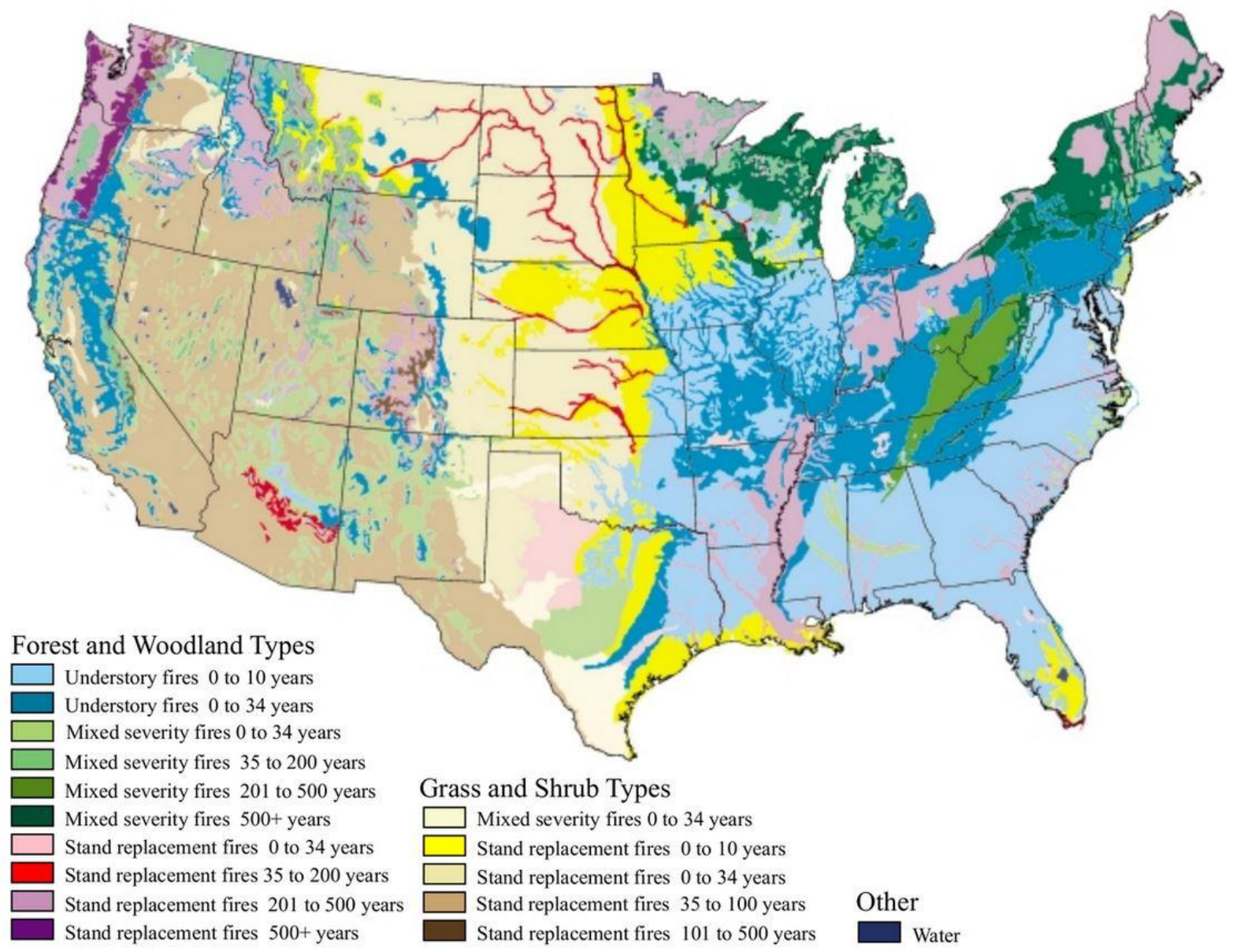

Figure 1 - Map showing the fire intervals for different types of wildfires in USA [19]

Not only wildfires, but also storms, droughts and epidemics create dynamic gap phases in arboreal vegetation and thereby contribute to the dynamics of the relationship between arboreal and non-arboreal vegetation in mosaic landscapes [21-23]. The famous elm-decline, interpreted by Troels Smith as a reflection of early agricultural fodder collection in Denmark [24], has subsequently been convincingly demonstrated to be closely related to a much larger-scale attack of Dutch elm disease [e.g. 25-27], which must have created extensive tree-less spaces in prehistoric mosaic landscapes. This is, of course, likely to have interfered locally with Neolithic landscape management in some areas [e.g. 28].

The flooding of low-lying areas around rivers and lakes also tends to create tree-less gaps of varying extent, characteristics and dynamics, depending on the frequency, periodicity and level of these inundations in relation to the local topography, as well as regularity/irregularity of their flow $[9$, p. 92, 161; 29; 30]. Economically important prehistoric coastal areas were not only influenced in similar ways by flooding but were also heavily impacted at times by tsunamis, which caused vegetation gaps in the landscape in the form of landslides, etc. [e.g. 31; 32]. 


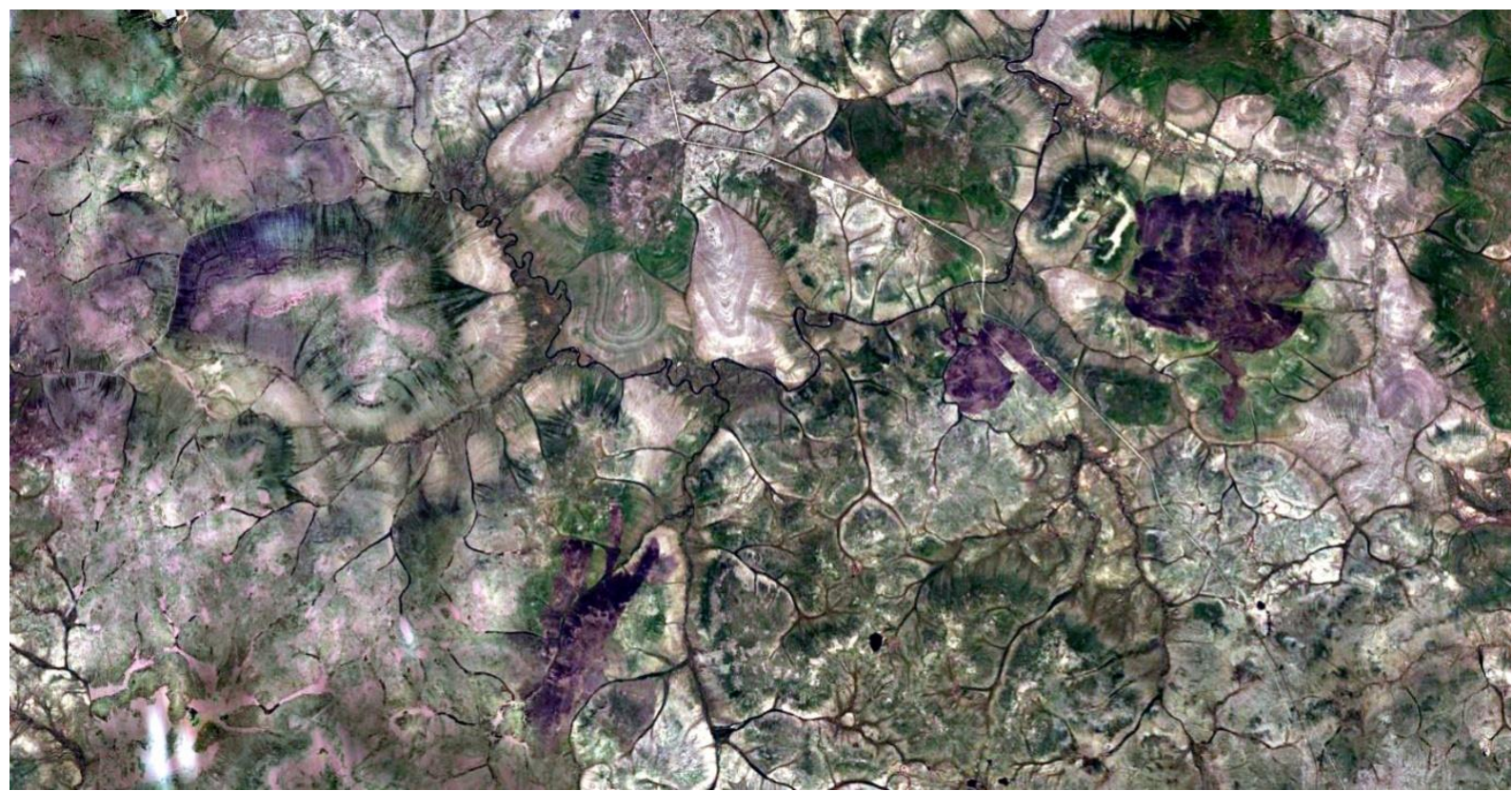

Figure 2 - Landscape mosaic in Siberia covering an area of $65 \times 35 \mathrm{~km}$ with its centre located at 544106 E 7283045 N UTM zone 49W. Several black burnt patches from wildfires can be seen. Google Earth

In addition to the vegetation dynamics, several further seasonal factors influence resource distribution in the landscape and thereby potential settlement locations, for example snow conditions (some conditions are easier for reindeer to walk in/on and to graze through etc.), naled areas (lakes and rivers frozen until late summer, which are attractive to reindeer etc., because the cold air above the ice make them mosquito free), significant local temperature variations in mountain areas (warm and cold valleys as well as deep lakes functioning as climate buffers) etc. [8]. Consequently, prehistoric nature, previously conceived as stable and homogeneous with randomly distributed resources, must now be perceived as highly dynamic with a mosaic-like and dynamic resource distribution.

\section{Archaeological consequences}

of a new landscape ecological understanding

Given recognition of these dynamics and complexity in landscape ecology, it seems relevant to ask whether it is possible to model potential Stone Age habitation areas at a sufficiently detailed scale for this to be meaningful in relation to an actual archaeological survey. A parallel discussion is also found in landscape ecology itself; about the scale at which landscapes can be reconstructed with reasonable precision [33-35]. The difference between these two research fields is that the landscapes and the plant and animal species they contain, as well as the interactions between these down to the individual level, can be studied directly and thereby provide significantly better data for modelling than is the case for Stone Age sites. A large proportion of the latter are more or less impossible to detect and map because they are either covered by sediment or have been destroyed by erosion. Those which are preserved and have been recorded are likely to represent restricted cultural activities and situations and cannot therefore be regarded as generally representative; it explains why the modelling based on them is so problematic.

Something which complicates the modelling of these resources in prehistory, and consequently the identification of potential settlement areas, even further is that var- ious hunter-gatherer cultures apparently interact with the complex and dynamic resources in their environment in different ways. While plant and animal populations can be modelled based on a reasonable assumption of uniform behavioural patterns for individual species, this is not so for hunter-gatherer cultures. To model settlement locations for a particular culture on a reasonable basis, it is first necessary to establish the culture's resource strategy/ies and related settlement behaviour [8; 13].

A rather primitive example of archaeological settlement modelling is the Danish so-called 'fishing-site model' for coastal sites, which postulates that Stone Age settlements are predominantly found in a few model topographical situations. These type-situations are sketched graphically but are accompanied by very little precise description. This modelling approach was introduced by the Danish Agency for Culture for predictive mapping of submerged Stone Age sites and has also been applied internationally [1;3] (fig. 3). It is interesting that it has not been possible to find published in the literature as a basis for this modelling method, a systematic data analysis covering an area which could be assumed to contain a fairly representative sample of settlement sites, as well as a systematic testing of the validity of the 'unlikely settlement zones' it postulates.

Analysis of the distribution of Late Mesolithic coastal settlements in a couple of well-surveyed areas, where these sites can be recorded today in relation to their contemporaneous shoreline, which corresponds to or is above present sea level, produced a picture which differed significantly from that postulated by the fishingsite model. Some of the settlements in the Karrebæksminde Fjord system are located in accordance with the model, but this is not true of the majority (figs. 3, 4) [36]). Analysis of the positions of Mesolithic and Neolithic shell middens, relative to the former coastline, in the well-surveyed Limfjord area, northern Jutland, gave a similar result (figs. 3, 5) [37, p. 157]. In both cases, a significant number of sites were found along the sides as well as close to the bottom of inlets, i.e. positions that are not predicted by the model. 

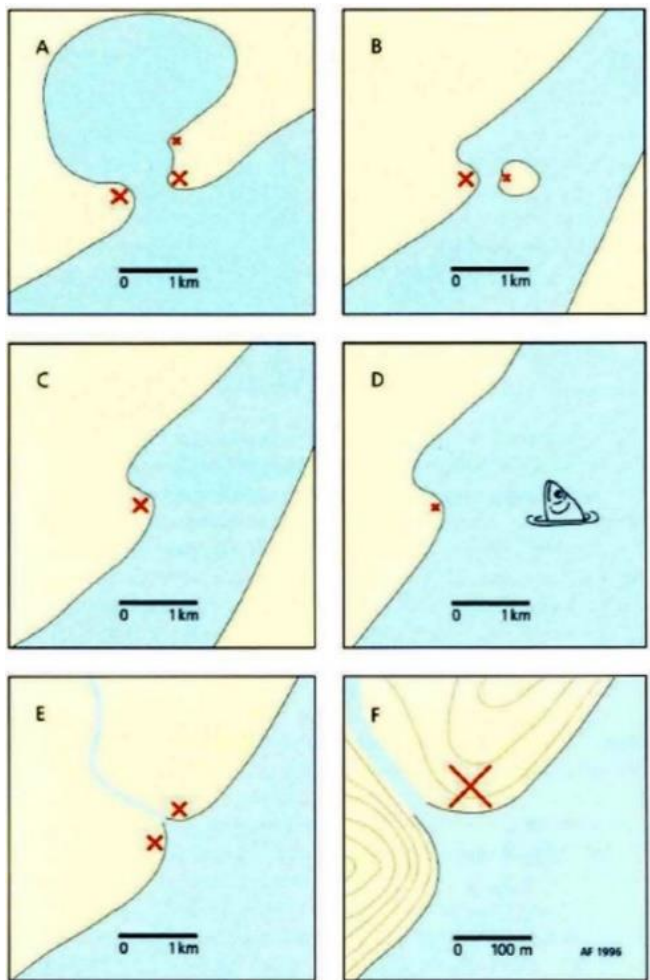

Figure 3 - Typical settlement positions for prehistoric hunters exploiting marine resources [3]

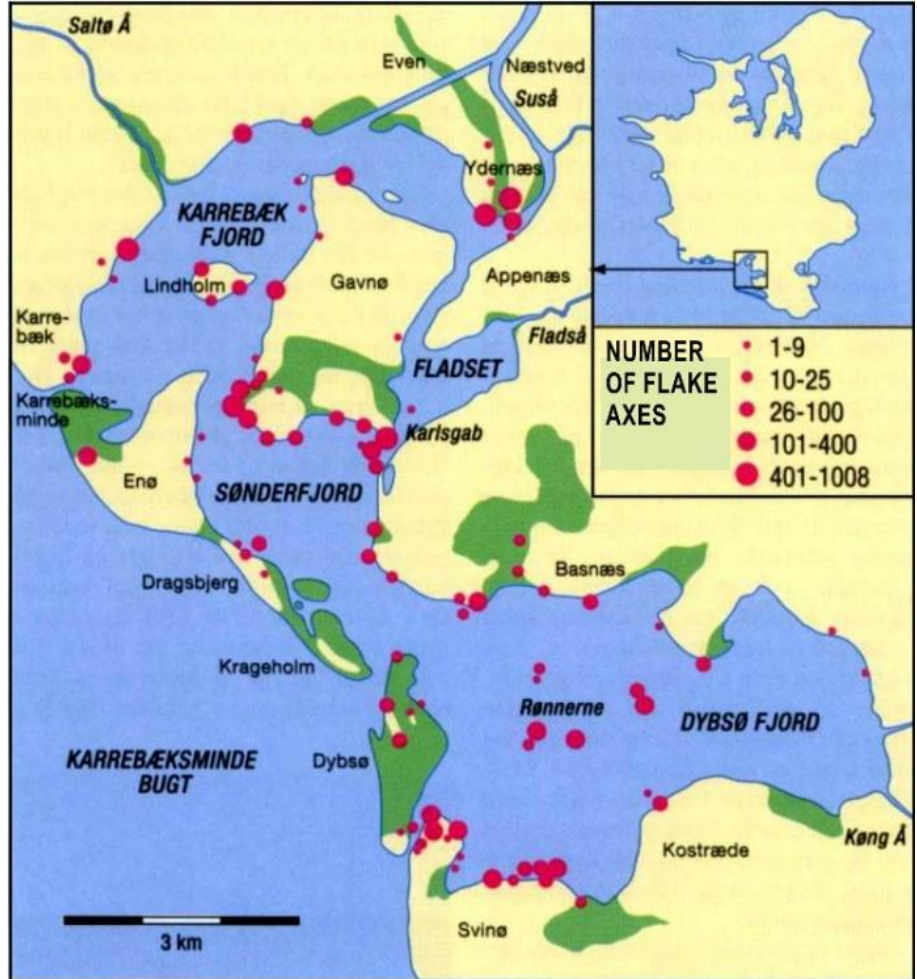

Figure 4 - The Karrebækminde Fjord system showing recorded Late Mesolithic sites. The size of the red dots signifies the number of flake axes found on the sites and thereby serves as an indication of the site's size

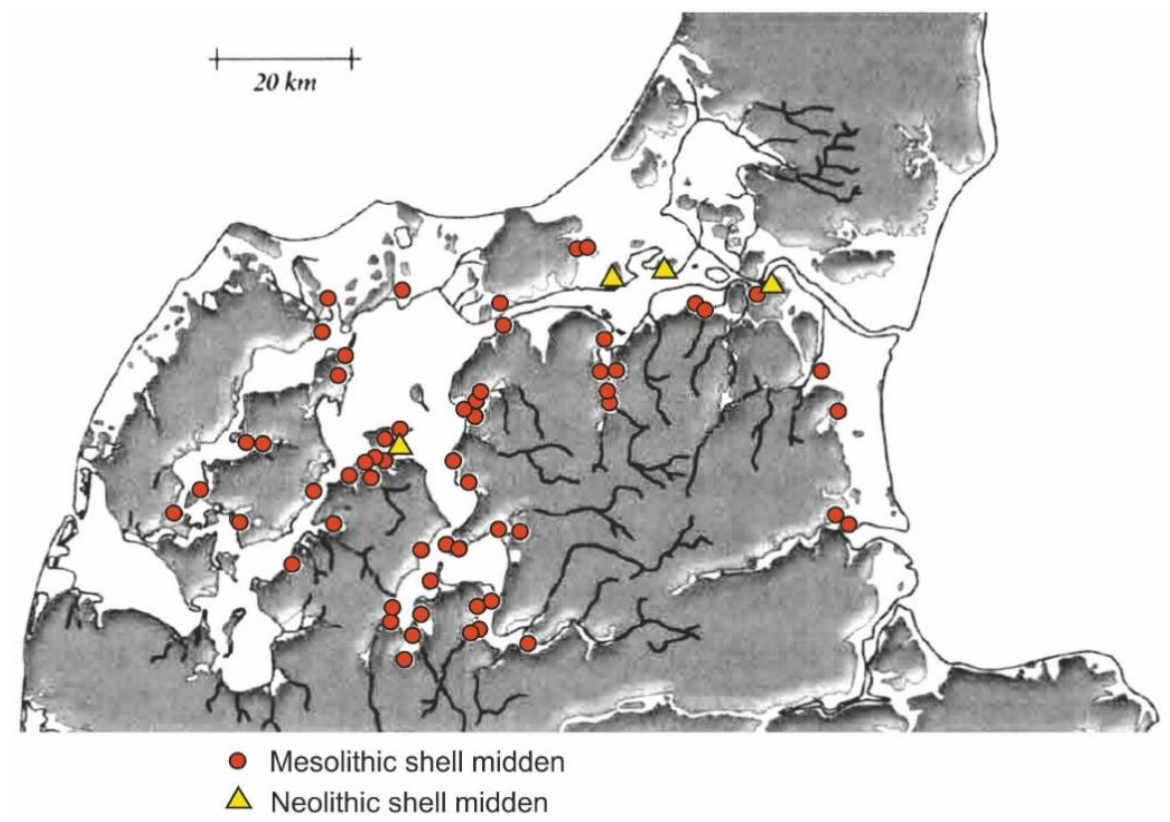

Figure 5 - The Limfjord showing the locations of Mesolithic and Neolithic shell middens [37, p. 157]

Analysis of available Danish maritime archaeological survey reports up to 2015 shows that systematic surveys of a total of $316,9 \mathrm{~km}^{2}$, based on the fishing-site model, has led to the recording of 15 'new' Stone Age sites $\left(=0,05\right.$ per $\left.\mathrm{km}^{2}\right)$. Random recording on land of a total of $2192,7 \mathrm{~km}^{2}$ in several selected Danish counties has led to the recording of 3258 'new' Stone Age sites (=1,48 per $\mathrm{km}^{2}$ ). Systematic surface survey on land of a total of $33,8 \mathrm{~km}^{2}$ in two areas on Zealand, Denmark, has led to the recording of 291 'new' Stone Age sites (=8,61 per $\mathrm{km}^{2}$ ). The density of submerged Stone Age sites recorded during systematic survey in accordance with the fishing-site model therefore represents $0,6 \%$ of the density of Stone Age sites recorded on land during systematic surface survey [38].

Even though it can be debated whether this $0,6 \%$ should be adjusted slightly upwards, the results outlined above indicate indisputably that something is seriously wrong with the basic 'topographical' assumptions behind the fishing-site model. One implicit, and possibly erroneous, premise underlying the fishing-site model is the idea that when groups exploited marine resources, they let these determine their settlement locations. Data from many parts of the world show that Mesolithic and Upper Palaeolithic cultures who exploited marine resources also took inland resources into account in their settlement 
positioning strategy. In several cases, their sites are found to be located several kilometres inland from the contemporaneous coastline, such that marine resources had to be transported quite a distance [39-49]. While the fishing-site model is based on the assumption that marine resources alone governed the location of sites, an improvement would be to assume that land resources may also have played a role.

Logically, modelling of the locations of non-maritime subsistence sites is subject to similar potential misunderstandings. This is, however, more difficult to demonstrate in a quantitative way, as we do not have better data for comparison.

Recently, agent-based modelling (ABM) has been introduced in an attempt to solve the problems with the earlier types of predictive modelling. However, the literature dealing with this development does not explain: 1) how such systems, in the absence of sufficient available environmental data, can model in adequate detail the prehistoric environmental small-scale dynamics that generally play an important role in the choice of actual settlement locations and 2) how they can reconstruct the different approaches and behaviours adopted by various cultural groups in relation to small-scale resources patterns [e.g. 50, p. 62-76; 51]. A qualified guess is that $\mathrm{ABM}$, in spite of its many positive qualities, is unsuited to detailed 're-creation' of lost landscape scenarios and their small-scale dynamics on the basis of absent data, as well as the reconstruction of behaviour related to these dynamic landscape situations, based on different cultural 'logic' which may well deviate from strict mathematical logic.

A further consequence of recent developments in landscape ecology is that approaches to studies of prehistoric resources, such as archaeological site-catchment analysis, must be regarded as outdated. The latter assumes an even distribution of stable resources in the prehistoric landscape; a view that belongs to an earlier generation of landscape ecology. Subsequent attempts to update this approach by integrating it into the application of GIS techniques have not solved the basic problem of establishing a sufficiently precise spatio-temporal environmental framework $[52 ; 53]$.

\section{Conclusion}

It is obvious from the above that there are several serious problems associated with predictive modelling of the locations of Stone Age hunter settlements in the landscape. The basic assumption that floral and faunal elements had a rather even distribution in the prehistoric landscape is in direct conflict with current views in landscape ecology. There is a need to update archaeological predictive modelling to a level where it can cope with the evident complexity of the prehistoric landscape situations it addresses.

The current theoretical situation is that it is possible to identify several severe problems with the way in which predictive modelling is presently applied to Stone Age archaeology, while not seeing a logical path to resolving these. At its present stage of development, the methodology is out of tune with contemporary landscape ecology and does not consider differences in cultural behaviour. Furthermore, it is possible to demonstrate in one tangible case (the fishing-site model) that its efficiency is surprisingly low.

Instead of accepting defeat on the modelling front, which is one possible outcome of the debate, we should be aware of potential alternative methods, involving direct physical detection of Stone Age sites, which currently appear to be developing in a quite promising way $[13 ; 54]$.

\section{References:}

1. Benjamin J. Submerged Prehistoric Landscapes and Underwater Site Discovery: Re-evaluating the 'Danish Model' for International Practice // Journal of Island \& Coastal Archaeology. 2010. Vol. 5. P. 253-270.

2. Chang-Martínez L.A., Mas J.-F., Valle N.T., Torres P.S.U., Foldan W.J. Modelling Historical Land Cover and Land Use: A Review from Contemporary Modelling // International Journal of Geo-Information. 2015. Vol. 4. P. 1791-1812.

3. Fischer A. Submerged Stone Age - Danish examples and North Sea potential // Submarine prehistoric archaeology of the North Sea. Research priorities and collaboration with industry. CBA Research Report 141 / ed. N.C. Flemming. 2004. P. 23-36.

4. Fitch S., Gaffney V., Thompson K. In Sight of Doggerland: From speculative survey to landscape exploration // Internet Archaeology. 2007. Vol. 22. P. 1-10.

5. Kamermans H., van Leusen M., Verhagen P. Archaeological Prediction and Risk Management // Alternatives to current practice. ASUL 17. Leiden: Leiden University Press, 2009.

6. Bjørnstad K., Rolf A., Lambin X. Spatial population dynamics: analysing patterns and processes of population synchrony // Trends in Ecology \& Evolution. 1999. Vol. 14 (11). P. 427-432.

7. Bode M., Possingham H. Optimally managing oscillating predator-prey systems // MODSIM05 International congress on Modelling and Simulation / eds. A. Zerger, R.M. Argent. Melbourne, 2005. P. 20542060.

8. Grøn O. Our grandfather sent the elk - some problems for hunter-gatherer predictive modelling // Quartär. 2012. Vol. 59. P. 175-188.

9. Odum E.P., Barrett G.W. Fundamentals of Ecology. Thomson Brooks/Cole, Belmont, CA, 2005.

10. Turner M.G., Gardner R.H. Landscape Ecology in Theory and Practice // Pattern and Process. New York: Springer, 2015.

11. Vandermeer J. Oscillating Populations and Biodiversity Maintenance // BioScience. 2006. Vol. 56 (12). P. 967-975.

12. Groß D., Zander A., Boethius A., Dreibrodt S., Grøn O., Hansson A., Jessen C., Koivisto S., Larsson L., Lübke H., Nilsson B. People, lakes and seashores: Studies from the Baltic Sea basin and adjacent areas in the early and Mid-Holocene // Quaternary Science Reviews. 2018. Vol. 185. P. 27-40.

13. Grøn O. Some problems with modelling the positions of prehistoric hunter-gatherer settlements on the basis of landscape topography // Journal of Archaeological Science. 2018. Reports 20. P. 192-199.

14. Hansson L., Fahrig L., Merriam G. Preface // Mosaic Landscapes and Ecological Processes / eds. L. Hansson, L. Fahrig, G. Merriam. London: Chapman \& Hall, 1995. P. xvi-xix.

15. Belsky A.J. Spatial and temporal landscape patterns in arid and semi-arid African savannas // Mosaic Landscapes and Ecological Processes / eds. L. Hansson, L. Fahrig, G. Merriam. London: Chapman \& Hall, 1995 P. 31-56. 
16. Saito K. Flames // Forest Fires. Behavior and Ecological Effects / eds. E.A. Johnson, K. Miyanishi. San Diego: Academic Press, 2001. P. 11-54.

17. Sommers W.T., Colof S.G., Conrad S.G. Fire History and Climate Change. Report Submitted to the Joint Fire Science Program for Project 01-2-01-09. https://firescience.gov/JFSP_fire_history.cfm. 2011.

18. Weber R.O. Wildland Fire Spread Models // Forest Fires. Behavior and Ecological Effects / eds. E.A. Johnson, K. Miyanishi. San Diego: Academic Press, 2001. P. 151-169.

19. Wildland Fire in Ecosystems. Effects of Fire on Flora. United States Department of Agriculture. Forest Service. Rocky Mountain Research Station. General Technical Report RMRS-GTR-42-volume 2 / eds. J. Brown, J.K. Smith. 2000.

20. Jasiewicz J., Sobkowiak-Tabaka I. Geo-spatial modelling with unbalanced data: modelling the spatial pattern of human activity during the Stone Age // Open Geosciences. 2015. Vol. 7. P. 289-307.

21. Barrett G.W., Shugart H.H. Significant theories, principles, and approaches that emerged within landscape ecology during the previous thirty years // History of Landscape Ecology in the United States / eds. G.W. Barrett, T.L. Terry, J. Wu. New York: Springer Science \& Business Media, 2015, P. 103-123.

22. Shugart Jr H.H., Corcoran W.W. Models of the Dynamics of Mosaic Landscapes // Bulletin of the Ecological Society of America. 2014. Vol. 95 (2). P. 117-120.

23. Watt A.S. Pattern and process in the plant community // The Journal of Ecology. 1947. Vol. 35, № 1/2. (Dec., 1947). P. 1-22.

24. Troels-Smith J. Ivy, Mistletoe and Elm. Climate Indicators - Fodder Plants // A Contribution to The Interpretation of the Pollen Zone Border VII-VIII. Geological Survey of Denmark. IV. Series. 1960. Vol. 4, № 4.

25. Grøn O. Neolithization in Southern Scandinavia A Mesolithic Perspective // Harvesting the Sea, Farming the Forest. The Emergence of Neolithic Societies in the Baltic Region / eds. M. Zvelebil, L. Domanska, R. Dennell. Sheffield: Sheffield Academic Press, 1998. P. 181-191.

26. Perry I., Moore P.D. Dutch elm disease as an analogue of Neolithic elm decline // Nature. 1987. Vol. 326. P. 72-73.

27. Rasmussen P. Leaf-foddering of livestock in the Neolithic: archaeobotanical evidence from Weier, Switzerland // Journal of Danish Archaeology. 1991. Vol. 8. P. 51-71.

28. Batchelor C.R., Branch N.P., Allison E.A. et al. The timing and causes of the Neolithic elm decline: New evidence from the Lower Thames Valley (London, UK) // Environmental Archaeology. 2014. Vol. 19 (3). P. 263-290.

29. Myster R.W. Flooding $\times$ tree fall gap interactive effects on blackwater forest floristics and physical structure in the Peruvian Amazon // Journal of Plant Interaction. 2015. Vol. 10 (1). P. 126-131.

30. Zhu C., Zhu J., Zheng X. et al. Comparison of gap formation and distribution pattern induced by wind/ snowstorm and flood in a temperate secondary forest ecosystem, Northeast China // Silva Fennica. 2017. Vol. 51 (5). P. 15.

31. Loosey R.J. Earthquakes and tsunami as elements of environmental disturbance on the Northwest Coast of North America // Journal of Anthropological Archaeology. 2005. Vol. 24. P. 101-116.
32. Weninger B., Schulting R., Bradtmöller M., et al. The catastrophic final flooding of Doggerland by the Storegga Slide tsunami // Documenta Praehistorica. 2008. Vol. XXXV. P. 1-24.

33. Levin S.A. The Problem of Pattern and Scale in Ecology: The Robert H. MacArthur Award Lecture // Ecology. 1992. Vol. 73 (6). P. 1943-1967.

34. Urban D.L. Modelling Ecological Processes Across Scales // Ecology. 2005. Vol. 86 (8). P. 1996-2006.

35. Winthers M.A., Meentemeyer V. Emergence of the Spatial Dimension in Ecology and Landscape Ecology // Landscape Ecological Analysis: Issues and Applications / eds. J.M. Klopatek, R.H. Gardner. New York: Springer, 1999. P. 206-208.

36. Johansson A.D. Ertebøllekulturen i Sydsjælland // Aarbøger for Nordisk Oldkyndighed og Historie 1997. 1999. P. 7-88.

37. Jensen J. Danmarks Oldtid. Stenalder 13.0002.000 f.Kr. Gyldendal, Copenhagen, 2001.

38. Grøn O. Fiskeplassmodellen, en metode for lokalisering av steinalderboplasser under vann - eller det motsatte? // Norsk Maritimt Museum Årbok. 2014. P. 235-244.

39. van Andel T.H., Lianos N. High-Resolution Seismic Reflection Profiles for the Reconstruction of Postglacial Transgressive Shorelines: An Example from Greece // Quaternary Research. 1984. Vol. 22. P. 31-45.

40. Arias P., Cuenca E.C., Fernández E.Á., Pellón E.G., Cordero A.G. A view from the edges: the Mesolithic settlement of the interior areas of the Iberian Peninsula reconsidered // Mesolithic Horizons: Papers presented at the Seventh International Conference on the Mesolithic in Europe, Belfast 2005 / eds. S.B. McCartan, R.J. Schulting, G. Warren, P. Woodman. Oxford, 2009. P. 303-311.

41. Colonese A.C., Mannino M.A., Bar-Yosef Mayer D.E., et al. Marine mollusc exploitation in Mediterranean prehistory: An overview // Quaternary International. 2011. Vol. 239. P. 86-103.

42. Gutiérrez-Zugasti I., Andersen S.H., Araújo A.C., et al. Shell midden research in Atlantic Europe: State of the art, research problems and perspectives for the future // Quaternary International. 2011. Vol. 239. P. 70-85.

43. Habu J., Matsui A., Yamamoto H., Kanno T. Shell midden archaeology in Japan: Aquatic food acquisition and long-term change in the Jomon culture // Quaternary International. 2011. Vol. 239. P. 19-27.

44. Haws J.A., Funk C.L., Bendetti M.M., et al. Palaeolithic Landscapes and Seascapes of the West Coast of Portugal // Trekking the Shore. Changing Coastlines and the Antiquity of Coastal Settlement / eds. N.F. Bicho, J.A. Haws, L.G. Davis. Springer: New York, 2011. P. 203-246.

45. Orquera L.A., Legoupil D., Piana E.L. Littoral adaptation at the southern end of South America // Quaternary International. 2011. Vol. 239. P. 61-69.

46. Rabett R., Appelby J., Blyth A., et al. Inland shell midden site-formation: Investigation into a late Pleistocene to early Holocene midden from Tràng An, Northern Vietnam // Quaternary International. 2011. Vol. 239. P. 153-169.

47. Saunders R., Russo M. Coastal shell middens in Florida: A view from the Archaic period // Quaternary International. 2011. P. 38-50.

48. Szabo K., Amesbury J.R. Molluscs in a world of islands: The use of shellfish as a food resource in the 
tropical island Asia-Pacific region // Quaternary International. 2011. Vol. 239. P. 8-18.

49. Wagner G., Hilbert K., Bandeira D., et al. Sambaquis (shell mounds) of the Brazilian coast // Quaternary International. 2011. Vol. 239. P. 51-60.

50. Rocks-Macqueen 2016: Agent Based Predictive Models in Archaeology. PhD thesis, University of Edinburgh.

51. Verhagen P., Whitley T.G. Integrating Archaeological Theory and Predictive Modelling: a Live Report from the Scene // Journal of Archaeological Method Theory. 2012. Vol. 19. P. 49-100.

52. Hunt E.D. Upgrading site-catchment analyses with the use of GIS: investigating the settlement patterns of horticulturalists // World Archaeology. 1992. Vol. 24, № 2, Analytical Field Survey (Oct., 1992). P. 283-309.

53. Jarman M.R., Vita-Finzi C., Higgs E.S. Site catchment analysis in archaeology // Man, settlement and urbanism / ed. P. Ucko, R. Tringham, G.W. Dimbleby. London, 1972. P. 61-66.

54. Hermand J.-P., Grøn O., Asch M., Ren Q. Modelling flint acoustics for detection of submerged Stone Age sites. Proc. OCEANS'11 MTS/IEEE Kona Conf. (Oceans of Opportunity: International cooperation and partnership across the Pacific), Institute of Electrical and Electronics Engineers, IEEE, 2011. 9 p.

\section{ПРОСТРАНСТВЕННО-ВРЕМЕННАЯ ДИНАМИКА РЕСУРСОВ В «ДИКИХ» ДОИСТОРИЧЕСКИХ ЛАНДШАФТАХ}

\section{(C) 2018}

Грён Оле, доктор наук, научный сотрудник кафедры наук о Земле и управления природными ресурсами Копенгагенский университет (2. Копенгаген, Королевство Дания)

Аннотащия. На основе археологических и этноархеологических данных в этой статье обсуждается пространственно-временная динамика ресурсов в «диких» доисторических ландшафтах, т.е. ландшафтах, не подвергавшихся воздействию современного монокультурного сельского хозяйства, но потенциально испытавших влияние другими способами. В археологической среде, занимающейся моделированием расположения поселений каменного века, преобладает мнение, которое заключается в том, что ресурсы в таких ландшафтах довольно стабильны и равномерно распределены. Однако такая концепция была оставлена в ландшафтной экологии в середине 1990-х годов, поскольку она не соответствовала наблюдаемой экологической реальности и была заменена на гораздо более сложные математические модели, допускающие, что различные виды растений и животных, как правило, появляются в высокодинамичных «микроареалах». Таким образом, обновление археологических дебатов и исследовательских инициатив, связанных с моделированием районов обитания в каменном веке, давно назрело. Центральной проблемой в этом отношении является то, следует ли считать динамическое пространственно-временное поведение ресурсов в этих ландшафтах настолько сложным, что его восстановление в конкретных микрорайонах, а значит и точное моделирование потенциальных зон поселений каменного века, невозможно. Тот факт, что человеческие культурные группы, в отличие от животных и растительных сообществ, часто демонстрируют различное поведение в сходных экологических ситуациях из-за того, что они разработали разные стратегии и традиции, не оставляет большой надежды.

Ключевые слова: топографическое моделирование ландшафтов; структура поселений охотников-собирателей; экономика охотников-собирателей; динамика ресурсов; собиратели; ландшафтная экология; локальная динамика; мозаичные ландшафты; лесные пожары; последствия штормов и наводнений.

УДК 903.7

DOI 10.24411/2309-4370-2018-14203

Статья поступила в редакцию 26.08.2018

\section{ПИЩЕВЫЕ РЕСУРСЫ В ЭКОНОМИКЕ И РИТУАЛЬНЫХ ПРАКТИКАХ СЕВЕРОМЕСОПОТАМСКИХ СООБЩЕСТВ ПЕРЕХОДНОЙ К НЕОЛИТУ ЭПОХИ}

(C) 2018

Корниенко Татьяна Владимировна, кандидат исторических наук, доцент кафедры зарубежной истории Воронежский государственный педагогический университет (2. Воронеж, Российская Федерация)

Аннотащия. Окончательное утверждение сельскохозяйственной экономики в центральной зоне Плодородного полумесяца произошло в период позднего докерамического неолита (PPNB), тогда как взлет символизма, выстраивание сложных общественных отношений у населения Северной Месопотамии приходится на эпоху раннего докерамического неолита (PPNA). Для этого времени в Юго-Восточной Анатолии (районе, где открыт долговременный межплеменной культовый центр Гёбекли Тепе), в отличие от соседнего Леванта, доместикация каких-либо видов растений еще не фиксируется. В статье обсуждаются возможные модели становления производящего хозяйства в рассматриваемом регионе, анализируются материалы, дающие основание полагать, что ритуальные практики эпохи перехода к неолиту в ряде случаев могли способствовать появлению и распространению новых экономических стратегий на территории Северной Месопотамии. При этом сопоставление результатов естественнонаучных исследований климатических изменений, археоботанических и археозоологических коллекций и материальных свидетельств развития социальной и духовной жизни с памятников эпипалеолита и раннего неолита Северной Месопотамии показывает коэволюционное влияние человека и окружающей его природной среды. На наш взгляд, исходя из современных данных, нельзя утверждать первенство «революции символов» в процессе неолитизации по отношению к ранним попыткам культивирования растений. 